\title{
Of Education, Humanism and Civilizational Progress: An Explorative Study of Jaya Prithvi Bahadur Singh's Life and Work from the Perspective of 'Global Intellectual History'
}

\section{Stefan Lueder}

The Himalayas have long been perceived as a region at the margins between South Asia, Southeast Asia and Central Asia. Since the turn of the $21^{\text {st }}$ century, however, the area received continuously more scholarly attention, particularly with regards to historiography and historical research. Researchers started to explore the manifold historical connections, entanglements, and interdependencies of the Himalayas with its neighboring regions and the rest of the world, which have long been disregarded due to the prevalence of implicit methodological nationalism, historiographical isolationism, and exceptionalism. Anticipating these changing perspectives, my paper explores the life and works of Jaya Prithvi Bahadur Singh in an attempt to render the global historical connections of the Central Himalayas further visible and enrich broader debates from the perspective of 'Global Intellectual History'. At the intersection of this newly emerging discipline and the intellectual history of the Himalayas, my paper seeks to address the research questions: Who was Jaya Prithvi Bahadur Singh and why is his life and work relevant for a better understanding of the multifaceted historical entanglements of the Central Himalayas? I argue that Jaya Prithvi's thoughts, specifically those on education, humanism, and civilizational progress will add new thematic dimensions, empirically diversify and, thus, broaden the scope of contemporary discourses on 'Global Intellectual History' as well as Himalayan History.

Keywords: global intellectual history; education; humanism; civilizational progress; Jaya Prithvi Bahadur Singh 


\section{Introduction}

Until recently, the area of the Himalayan Massif ${ }^{1}$ has generally been perceived as remote, inaccessible, and isolated, "as frontier, as refuge, or as borderland" (Saxer 2016: 105). In academia, the area has usually been located at the periphery of discursively defined sub-divisions of Asia, between South Asia, Southeast Asia and Central Asia, and has received comparably little scholarly attention. But, in the past two decades, the situation appears to be changing, as the region now attracts a continuously growing number of researchers from a variety of disciplinary backgrounds. ${ }^{2}$ This trend can also be observed more specifically with regards to historiography and historical research in the Central Himalayas. Researchers started to explore its manifold historical connections with its neighboring regions and the rest of the world, which have long been disregarded due to the prevalence of implicit methodological nationalism, historiographical isolationism, and exceptionalism.

In the case of Nepal, these tendencies can be traced back to the state-sponsored invention of a national historiographical narrative after 1951 and its propagation during the Panchayat system from 1960 until 1990. Anticipating the early and often implicit criticism of the works of Mahesh C. Regmi (1963-68) and Richard Burghart (1984), scholars have focused extensively on critical reflection of the national historiography since the 1990s (e.g., Pradhan 1991, Onta 1993, Manandhar et. al. 1995, Regmi 1995; 1999, Vaidya 1995; 2002, Raj 2014). They have explored the many desiderates, their origins, and discussed possibilities to address them (Onta 1994b; 1996a; 1997, Rupakheti 2012) and evaluated the current state of historical research and education (Raj and Onta 2014, Manandhar et. al. 2014; 2015). Parallel to this process of critical reflection, numerous scholars have paid increasingly more attention to the multi-layered historical connections of the region, addressing a wide range of issues like trade and politics, culture and identity, language and literature, state-making and nation-building, territory and law from transnational, transregional and even global perspectives (Mikesell 1988, Des Chene 1991; 2007, Liechty 1997, Chalmers 2003, Shneiderman 2010, Uprety 2011, Michael 2011; 2012, Michaels et. al. 2016, Saxer 2016, Rupakheti 2017, Pradhan 2019).

In an attempt to render the global historical entanglements of the Central Himalayas further visible, my paper follows the life and works of Jaya Prithvi Bahadur Singh to enrich broader issues and debates beyond the region and Asia from the perspective of 'Global Intellectual History'. At the intersection of this "discipline in the making" (Mulsow 2017: 1) and the intellectual history of the Himalayas, my paper seeks to address the research questions: Who was Jaya Prithvi Bahadur Singh and why is his life and work relevant for a better understanding of the multifaceted historical entanglements of the Central Himalayas? Besides introducing an intellectual to the discourse who does not belong to the "cast of the usual suspects" (Subrahmanyam 2015: 129), Jaya Prithvi's thoughts, specifically those on education, humanism and civilizational progress will add new thematic dimensions, empirically diversify and, thus, broaden the scope of contemporary discourses on 'Global Intellectual History' and Himalayan History as well.

\section{Jaya Prithvi Bahadur Singh and Global Intellectual History: An Overview on the Current State of Research}

Although little has been written on Jaya Prithvi outside of the Nepālì-speaking scholarly community, there exists a number of publications about his life and work. In the late 1950s and early 1960s, Jaya Prithvi had been studied with a distinct focus on his work regarding the language that later evolved into what is known as Nepāli today (Dixit 1957 [2014 V.S.], Pant 1961 [2018 V.S.]). However, during the Panchayat years he seemingly disappeared from scholarly discussions on linguistics. Until the political changes of the 1990s brought about a renewed interest in his work, particularly in his contributions to the development of Nepālī (Śarmā 1998 [2055 V.S.], Śarmā 1999 [2056 V.S.], Parājulī 2000 [2057 V.S.]). Concurrently, since the late 1970s and in the wake of increasing dissatisfaction of the population in Nepal with the Panchayat system, protests and the referendum of 1980, there has been continuously growing engagement with Jaya Prithvi's biography, his work on education, literature, and philosophy (Simha 1978 [2035 V.S.], Subedī 1979 [2036 V.S.], Piṇ̣̂ālī 1979 [2036 V.S.], Pande 1982 [2039 V.S.], Simha 1989 [2046 V.S.], Subedī 1990 [2047 V.S.], Bhatțarāī 1998 [2055 V.S.], Siṃha 1998 [2055 V.S.], Jośi 2012 [2069 V.S.]). Some scholars have argued that he should be regarded as one of the earliest leftist thinkers of the country (Dixit 1984 [2041 V.S.]). Almost the same can be said about publications in English by authors from Nepal. They focused either on his contributions with regards to the Nepālī language, his biography, or his educational, literary and philosophical publications, as well as his activism (Aryal 1970; 1977, Surendra 1999 [2056 V.S.], Khadka 2001, Barua 2002, Pokharel 2009, Parājulī 2012), claiming he was one of the early critics of the Rana family $^{3}$ and part of the "germination of leftist ideals in Nepal” (Thapa 2004: 21). By republishing many of Jaya Prithvi's works since the 1990s, the NGO Research Academica for Humanism and Jai Prithvi Bahadur Singh (RAFHAJ), today 
renamed as the Humanism and Jai Prithvi Foundation, has been at the forefront in trying to generate new attention and initiate debates about his ideas. ${ }^{4}$

But, whether researchers focus on Jaya Prithvi as a linguist, educator, intellectual, or activist, their discussions and investigations are exclusively conducted within the presupposed framework of the nation-state. They tend to portrait him as another bir puruș (Nep. brave man/hero), calling for the adequate acknowledgement of him in the pantheon of national or local heroes. ${ }^{5}$ As a consequence of this limited perspective, the manifold historical entanglements and connections remain largely unexplored. Fortunately, perspectives are beginning to change as Jaya Prithvi's thoughts on education and philosophy have very recently sparked some interest of news outlets in Nepal. From a comparative perspective, Katak Malla (2020a; 2020b) draws some parallels between Jaya Prithvi's work and the ideas of Buddhism and Antonio Gramsci ${ }^{6}$, while also criticizing Edward Said (2004) and Pankaj Mishra (2012) for not appropriately recognizing Jaya Prithvi's intellectual contributions to various discourses. To further advance this approach, move beyond the predominant methodological nationalism in historical research on the Central Himalayas, and broaden the scope of inquiry by analyzing and understanding Jaya Prithvi and his work through the lens of the emerging discipline of "Global Intellectual History' in an explorative study appears to be promising and necessary.

In contrast to the several decades of research on Jaya Prithvi, the idea of 'Global Intellectual History' is a much more recent one. It originated at a conference in April 2010 that prompted the publication of a volume edited by its organizers, Samuel Moyn and Andrew Sartori (2013). As the label implies and the authors explain, they situate their work on the intersection of the older and somewhat marginal field of 'Intellectual History' and the newly emerging one of 'Global History'. The volume generated widespread scholarly attention and vibrant discussion which led to the launch of the journal Global Intellectual History in $2016 .{ }^{7}$ Hence, those who are critically reflecting upon these recent developments are all in agreement that there exists yet no consensus on what the subject matter or the appropriate research methods for this newly emerging discipline could be and, more generally speaking, "what is meant by the label" (Thomson 2019: 134). In consequence, working at the intersection can be just as advantageous as problematic. As Martin Mulsow explains, scholars can draw from the diverse approaches of 'Intellectual History' using "conceptual history to network analysis, from the history of political languages to the philological study of texts" (Mulsow 2017: 1). But, at the same time, the idea of 'Global Intellectual History' likewise encompasses the deficits of its twofold origin. The major problem of 'Intellectual History' is its long-lasting implicit Euro- and Western-centrism (Sachsenmaier and Sartori 2018: 216). And the uncertainty on the subject matter, the methodology, and the labelling in general derives primarily from the uncertainty in the field of 'Global History' (Thomson 2019: 133).

According to Sebastian Conrad, 'Global History' is a revisionist approach through which scholars of history are seeking to move beyond the nation-state as the presupposed fundamental unit of inquiry in order "to arrive at a more comprehensive understanding of the interactions and connections that have made the modern world” (Conrad 2016: 5). Within “Global History', Conrad distinguishes three major variations: (1) the history of everything, (2) the study of connections, and (3) the study of particular cases situated in a global context (2016: 6-10). In a recent interview, Sanjay Subrahmanyam has criticized Conrad's differentiation, because it "seems to constitute sloppy thinking and careless use of language; it is not at all helpful," advocating instead for a more careful application of the already existing approaches of connected and comparative history (Barbu 2019: 123). However, the vantage point for this paper is the definition given by Sven Beckert and Dominic Sachsenmaier in the introduction to their edited volume:

[...] global history is both connected history and comparative history. On the most basic level, it is the search to understand how human societies have developed as an interactive community across the world. Searching for alternative modes of conceptualizing the past, global history examines processes, networks, identities and events that cross boundaries of modern states, regions and landmasses. Interested in circulation, global history focuses on the connections between people, ideas, fashions and commodities across borders. (Beckert and Sachsenmaier 2018: 3)

Several scholars have been just as critical of the endeavor of 'Global Intellectual History', especially of the continuing Euro- and Western-centric perspectives. But, even if authors move beyond the 'West-Rest' axis in an attempt to diversify their scope of research, there remains a residual lack of empirical diversity through tendencies to disproportionally focus on the modern period, the same few individuals, and a limited variety of themes only (Subrahmanyam 2015: 129-136). As a reaction, there 
have been several attempts to anticipate the criticism and thwart these tendencies (Haakonssen and Whatmore 2017, Subrahmanyam 2017, Pocock 2019). What has not been debated so far is the emergence of new centers beyond 'the West'. In the case of Asia specifically, the continuously growing tendency to focus empirically almost exclusively on India and China, replaces one form of centrism with another. A deliberate focus on the discursive and regional 'margins' in Asia, not well-known and studied individuals and their ideas, for example those of Jaya Prithvi Bahadur Singh on education, humanism, and civilizational progress could, therefore, help to thwart these inclinations, while simultaneously rendering translocal, transregional and even global historical entanglements of the region with the rest of the world visible, empirically diversifying and enriching broader debates that animate scholarship beyond the Himalayas and Asia.

\section{From Elite to Exile}

Jaya Prithvi Bahadur Singh was born in August 1877, in Chainpur to the Rānī Rudra Kumari Devi and Rājā Bikram Bahadur Singh of the rājya (Nep. principality) Bajhang, on the western border of the Gorkha state. ${ }^{8}$ His mother was a daughter of the very first Rana Prime Minister, Jung Bahadur Rana. ${ }^{9}$ Jaya Prithvi spent his early childhood with his family in Bajhang before moving to Kathmandu in 1885. ${ }^{10}$ There, he began his formal education in the pāțśálā of the Thapathali Durbar and Durbar High School to become a member of the administrative elite of the ruling Rana family. After Prime Minister Bir Shamsher Rana removed his father in 1889, Jaya Prithvi was designated as the new Rājā of Bajhang, at the age of 12. He left for Calcutta in 1893 to commence his university studies, and, shortly thereafter, in 1894 he married Khagaraja Divyeshwari Rajya Laxmi, a daughter of the later Prime Minister Chandra Shamsher Rana. ${ }^{11}$ He returned to Bajhang for about a year following his graduation, and then moved again back to Kathmandu in 1899 to serve in the administration of the Gorkha state under the rule of Prime Minister Bir Shamsher Rana (Simha 1978 [2035 V.S.]: 4-10).

During the short reign of Deva Shamsher Rana in 1901, Jaya Prithvi quickly rose through the ranks, becoming involved in the educational reform initiatives of the Gorkha state as a member of the influential royal advisory committee and chief editor of Gorkhāpatra, the country's first newspaper. ${ }^{12}$ Until then, access to education for the general population had been extremely limited and a privilege of the ruling elites. The very few existing educational institutions used either English, Sanskrit, Persian, or
Bengali as the medium of instruction, while the colloquial Parvatīya Bhāṣā ${ }^{13}$ was considered "not worthy" as such (Parājulī 2012: 300). Confronted with these challenges, Jaya Prithvi wrote and published a collection of schoolbooks in the vernacular to function as educational material. These materials enabled larger proportions of the population to access knowledge through the newly created institution of the Bhāṣā Pāthśāāā. Under the tutelage of Deva Shamsher Rana and guidance by Jaya Prithvi around fifty of those 'language schools' have been established across the country, with the majority inside the Kathmandu Valley. ${ }^{14}$

However, after the coup d'état of his father-in-law and the displacement of Deva Shamsher Rana, the funding for this educational reform initiative was cut and Jaya Prithvi ordered to serve as the vakila (Nep. representative) of the Government of the Gorkha state to the British Raj in Calcutta in 1902 (Foreign Department 1903a; 1903b). After the consolidation of power of the new Prime Minister, the political situation in Kathmandu eased and Jaya Prithvi was finally allowed to return in late 1905 and resume his career in the administration. He first went to Bajhang, where he established the Śrī Satyavādī Pāṭhśālā in early 1906 before moving on to Kathmandu to resume his administrative career. ${ }^{15}$ In the meantime, the gradually expanding state bureaucracy had generated an increasing demand for personnel to administer it, to ensure the collection of revenue, staff courts, offices and so forth. To provide the necessary training, the Rana Government began with the establishment of the Śrestā Pāthśālās in 1905, thus, earlier educational reform efforts were not completely abolished, but rather readjusted to serve the specific needs of the expanding administration (Parājulī 2012). Shortly after his return, Jaya Prithvi had seemingly proven his loyalty and was appointed chairman of the Bhārādārī Sabhā, the principal legislative body of the Gorkha state, and reinstated as chief editor of Gorkhāpatra. In these functions, he accompanied his father-in-law as part of the diplomatic entourage travelling to Europe in 1908 (Home Department 1908). In the following years, he continued to serve in various key positions of the Rana administration while he expanded his writing and publishing from education more into literary as well as philosophical themes.

The relationship between Jaya Prithvi and Prime Minister Chandra Shamsher had always been tense, but it deteriorated further in the aftermath of the involvement of the Gorkha state in the 'Great War' on behalf of the British. The British had already been recruiting young men from the Himalayas for their regiments of the Gurkha Rifles since the end of the Anglo-Gorkha war (1814-1816) and had employed them in numerous military campaigns 
(Banskota 2014 [1994]). During World War I, recruitment reached its apogee and was by no means always voluntary (Onta 1994a). Between 1914 and 1918 approximately 200,000 young men from the Himalayas served in the ranks of the British Indian Army on the numerous battlefields of Europe and Asia, leaving 20,000 dead and an unknown number injured, captured, and imprisoned. In retrospect, it appears as if these global developments, the policy of heavy involvement of the Gorkha state in the war in Europe, the tragedy that followed, and the impact it had in the Central Himalayas might have contributed significantly to the fall-out between Jaya Prithvi and Chandra Shamsher. ${ }^{16}$ Even though I was not able to locate any documentation providing insights into Jaya Prithvi's personal motivation, he, ultimately, decided to change the course of his life. He left all his official positions in the administration and resettled in the British territory of the Kumaon Himalaya, thereby entering his self-imposed exile around 1918 (Foreign and Political Department 1918). ${ }^{17}$

Archival documents further reveal that Jaya Prithvi purchased land in the British Civil and Military Station in Bangalore around 1921 and permanently resettled in his newly constructed Jaya Bhavan in 1924 on the waterfront of Ulsoor Lake (Foreign and Political Department 1921). In the years thereafter, he came to know P.R. Singarachari, a lecturer in history at St. Joseph's College, who assisted him with the English translation of his philosophical works. Their cooperation turned out to be very fruitful and culminated in 1928 in the publication of the book Humanism in three volumes and the foundation of the Humanistic Club with Jaya Prithvi as its president. ${ }^{18}$ In a lecture at the Jinnah Hall in Bombay in 1929, Jaya Prithvi elaborates the idea on which the club had been founded, its name and major objective:

With this object in view, to work with persons individually for the promotion of peace and goodwill, I started an institution in Bangalore under the name of "The Humanistic Club". [...]. My object in using the words "Humanistic" and "Club" combined is twofold: first, to avoid any sectarian colouring being given to the movement; second, to make it easily acceptable to all human beings irrespective of cast, creed, class or colour [...]. In fact, the chief object of this Club is to gather firsthand knowledge of all that is best for human interest and benefit from all possible sources and to spread far and wide through its members the efficacy of such knowledge. (Siṃha 1997 [1930]: 41-42)
The Humanistic Club began to organize weekly meetings in the Jaya Bhavan, discussing a variety of issues concerning religion, philosophy and society, hosting guest lectures and publishing a monthly journal in English titled The Humanist, which published "an account of the activities of the Club, the Lectures delivered during its Weekly Meetings, and deals with Religion, Philosophy, Sociology, Psychic Phenomena etc.” (Siṃha 1930: i). Further, Jaya Prithvi was convinced that the ideas of the Humanistic Club should not be restricted to a specific audience of intellectuals on the South Asian subcontinent, but rather be disseminated throughout the entire world. The major problem he was facing to accomplish this objective was the lack of funding. Jaya Prithvi unsuccessfully approached his father-in-law for financial support. He then turned to apparently desperate means, staged his own abduction and demanded ransom money from his family (Foreign and Political Department 1928; 1929). Though the sham was discovered later on, Jaya Prithvi was able to secure the funding for his planned tour and extensively traveled through Europe in 1929, and later on also to North America and East Asia, and spoke in front of diverse audiences in Geneva, Berlin, Prague, Vienna, Budapest, Belgrade, Warsaw, Paris, and London (Simha 1930). In 1933, he was invited to participate at the International Congress of the World Fellowship of Faiths in Chicago, and on his way back to British India, he gave speeches, engaged with other intellectuals, and established branch offices of the Humanistic Club in Tokyo, Shanghai and Rangoon. ${ }^{19}$

In the mid-1930s, Jaya Prithvi got involved as an activist in the Abyssinian War. The periodical Gorkhā Sevak ${ }^{20}$ reported on $12^{\text {th }}$ of February 1936:

According to news arrived via post Jaya Prithvi Bahadur Singh of Nepal is now in Abyssinia. [...]. Prior to that he was in Japan. He went there when the war between Italy and Abyssinia broke out. [...]. He also invited two doctors and four nurses from Japan. (Gurung, Gorkhā Sevak 1936) 21 $^{21}$

Other documents show that he was able to obtain a British Passport as a so-called "protected subject" of the Mysore state (Foreign and Political Department 1932). Supposedly, he not only brought medical assistance from Japan, but also managed to smuggle gas masks in a sting operation into Abyssinia (Siṃha 1978 [2035 V.S.]: 65). His activism was then terminated as he was captured and incarcerated by Italian forces and only through British intervention able to return to Bangalore. Subsequent to this episode, his British passport was revoked and from then on, he was confined to remain within the territory of the British 
Raj (Foreign and Political Department 1936). His situation further worsened with the outbreak of World War II. At first, he contacted British officials to offer his support by raising a small Red Cross Contingent that would support the Gurkha Rifles in the British Indian Army. But, in secret correspondence between officials of the Foreign Office in New Delhi and the Chief Secretary to the Government of the United Provinces in March 1940, it is discussed that Jaya Prithvi supposedly "for several years engaged in undesirable activities and is suspected of being a Japanese agent. The Government of India therefore refused his offer." (Political Department 1939). In addition, the administration issued an order that placed Jaya Prithvi under house arrest in April 1940. He then tried to convince the British administration of his innocence, writing a letter to the Secretary of the Home Department of the Government of India in May 1940, arguing:

Nobody can say that I was ever connected with any political movement or propaganda, or had ever lent my name to any subversive, revolutionary, reactionary or any mischievous movement. In fact, for quite a long time, for well-nigh 15 years, my activities, [...] were always strictly limited to literary, philosophical and humanistic pursuits, and since 1938 they have become still more limited and are wholly confined to humanitarian and philanthropic matters. (Foreign Department 1940: 195)

Unfortunately for him, the British officials did not react to his reasoning. Thereafter, Jaya Prithvi's health deteriorated fast, and he died in September 1940 in his Jaya Bhavan.

Generally speaking, Jaya Prithvi's biography consists of two major phases. At first, he was an influential member of the ruling administrative elite and, as a grandson of the first Rana Prime Minister, Jung Bahadur and son-in-law of Prime Minister Chandra Shamsher, part of the extended Rana family, enjoying all the privileges and access to the center of power of the Gorkha state that came with it. However, influenced by a variety of ideas and experiences he was exposed to during his service in government, he decided to leave his life in the Gorkha state behind and become an author, intellectual, and activist. In the later part of his life, he undoubtedly still lived a comparatively privileged life, but in self-imposed exile in the British Raj.

From this introductory overview of Jaya Prithvi's biography, a few preliminary conclusions can be drawn based on the available source material. With reference to the desiderates of the national historiographical narrative, the story of his life challenges the prevalent portrayal of the Rana-era as a "dark age" and Gorkha as a "fossil state" (Onta 1997), the implicit Kathmandu-centrism and isolationism in Central Himalayan historiography. Many of the social and cultural reforms initiated during the Panchayat years originated in efforts in the early years of the $20^{\text {th }}$ century, in some of which Jaya Prithvi played a significant role. Moreover, as a member of the ruling elite of the Rana family in the earlier part of his life, he was able to move constantly between the center of the Gorkha state, its periphery, and neighboring regions, namely Kathmandu, Bajhang, and the British Raj. And, while living in exile, he traveled to Europe, North America, Africa, and many parts of Asia. This mobility highlights the multiple connections of the Central Himalayas with its neighboring regions and the rest of the world in the early $20^{\text {th }}$ century.

Apart from this, it seems further evident that Jaya Prithvi had been concerned with the wellbeing of the general population of the Gorkha state during his years serving in the Rana administration. His engagement in the administration's reform initiatives, most notably regarding access to education for a larger proportion of the population, could be viewed as indicative of that objective. However, the later part of his life equally brings to light that he was not willing to refrain from all the privileges he enjoyed earlier. In exile, he did not work to earn his income, but instead continued to be financed by the Rana family and, thus, by the very same hardworking people in the Gorkha state from whom the Rana administration extracted their wealth in the first place. He lived quite lavishly not only in his residence in Naini Tal, but also at his lake side Jaya Bhavan in Bangalore. And, to cover for the additional expenses of his desired lecture tour around the globe, he chose to trick his family by staging his own abduction to demand ransom, utilizing their affection for him. The point is that Jaya Prithvi should not simply be understood as a forgotten hero insufficiently recognized in national historiography, but as an ambiguous, though remarkable personality who lived a fascinating life.

\section{Of Education, Humanism, and Civilizational Progress}

After engaging with the biography of Jaya Prithvi in the first part of this paper, in this second part I will focus on his actual publications in order to address the question of how far his publications can enrich larger debates in the emerging discipline of 'Global Intellectual History'. As the analysis of his complete body of work will easily lead to a monograph on its own, and access to original sources is limited, my attempt here is to provide an introductory overview with preliminary discussion of some selected publications. Undoubtedly, further research on each issue 
is required. To begin with, the corpus of publications by Jaya Prithvi can, congruently with his biography, roughly be divided into two parts: (1) early publications, written in Parvatīya Bhāșā and published during Jaya Prithvi's service in the Rana administration of the Gorkha state in the first two decades of the $20^{\text {th }}$ century; (2) later publications, written in English and published in the late 1920s and early 1930s.

Soon after Jaya Prithvi entered the Rana administration in 1901, he became an important advisor to Prime Minister Deva Shamsher Rana. He was entrusted with the major reform program to establish a primary education system in the Gorkha state and encountered the fundamental problem of the non-existence of educational textbooks in the colloquial Parvatīya Bhāṣā. Therefore, Jaya Prithvi compiled and published altogether four books in 1901, titled Akșarānika Śikșā, Bālbodh, Gyānmāāā and Śrestādarpaṇa (Siṃha 1901a, 1901b, 1901c, 1901d). The books Akșarānka Śikșā and Bālbodh were intended to convey basic alphanumeric knowledge so that respective students could gain an understanding of the Devanagari script, the numeral system, and elementary algebraic functions. Equipped with this knowledge, students were able to engage with the introduction to South Asian literature and philosophy in Gyānmālā and acquire the practical skills of bookkeeping through Śrestādarpana.

After Deva Shamsher was ousted as Prime Minster and exiled to British India, Jaya Prithvi continued to write during his time as vakila in Calcutta. In 1905, just after his return to Kathmandu, he published two more books, one was a philosophical sub-commentary titled Padārthatattva Viveka (Simha 1905a) on an issue of South Asian philosophy. The other one was the first part of the three-part series titled Śikșādarpana which could be translated as 'educational series' (Simha 1905b). This book starts with a general overview of what a virtuous life is and what kind of morals should be embraced, followed by several short stories and dialogues intended to illustrate the proclaimed ethos. The book then provides an overview about some selected historical figures, introducing the reader first to Christopher Columbus, Isaac Newton, and King Alfred (Alfred the Great), before summarizing the story of the Persian king Kay Khosrow from the epic poem Shahnameh (Pers. The Book of Kings) and the gambling match from the Sabhā Parva of the Mahābhārata. The book closes with a recount of the major battles of the Anglo-Gorkha war.

The second and third part of Śikșādarpana were subsequently published in 1907. In the second book, Jaya Prithvi provides the reader a lengthy and detailed history of South
Asia that seeks to understand the 'decline of Hindu civilization'. He reiterates the narrative of the 'Aryan arrival' theory, describing the establishment of 'Hindustan', the 'Muslim conquest' of the region, and the successive rise of the British power in South Asia (Simha 1907a). The third book is particularly interesting, as it contains a remarkably vivid description of the political, social, cultural, and economic history of Japan (Simha 1907b). In the final sentence of its introduction, Jaya Prithvi explains his choice of the example:

In order to understand the reasons for a country making progress (unnati), a short history of Japan has been written - a country that achieved great improvement (tarakki) within just a few years and recently defeated Russia, the largest country in the world. (Simha 1907b: 7) $)^{22}$

This statement is significant, because it shows that Jaya Prithvi participated in a discourse in the early $20^{\text {th }}$ century around the ideas of unnati (Nep. progress) and tarakki (Nep. improvement) inspired by the example of Japan. In the second chapter of her dissertation and an earlier paper, Bandana Gyawali $(2017 ; 2018)$ studied the conceptual history of these ideas during the Rana administration, arguing that saybhyat $\bar{a}$ (Nep. civilization) and unnati are precursors to the development discourse evolving around the concept of bikās (Nep. development) after 1951. Starting with the voyage of Jung Bahadur Rana to Europe in 1851, Gyawali first analyzes the travelogue of this journey and then looks at the speeches of the Rana Prime Ministers, dictionaries, and the literary magazine Śăradā to substantiate her thesis. Surprisingly, Jaya Prithvi and his publications are not mentioned once, though they could close the apparent gap of the debate in the early years of the $20^{\text {th }}$ century. This inclusion would additionally broaden the argument on the origins of the discourse, because the pre-bikās encounters of the Gorkha state were not limited in their orientation towards 'the West', as Jaya Prithvi was evidently looking towards 'the East' for inspiration as well.

Beyond that, the given explanation by Jaya Prithvi to study Japan specifically can be understood as part of a larger ongoing process that Pankaj Mishra (2012) termed the "intellectual revolt against the West" which drove the remaking and rethinking of Asia in the first half of the $20^{\text {th }}$ century. Like many of his peers in Asia, Jaya Prithvi saw the military victory of Japan over the Russian Empire in the Battle of Tsushima in May 1905 that terminated the Russo-Japanese war as a pivotal moment, a cesura in history. As Mishra puts it: "For the first time since the Middle Ages, a non-European country had vanquished a 
European power in major war; [...]" (Mishra 2012: 1). Prior to that, the Rana administration had already had several encounters with Japan. After the visit of the Buddhist monk Ekai Kawaguchi (1866-1945) in 1899, the Gorkha state had sent a group of eight students to Japan in April 1902 (Barua 2002). Jaya Prithvi's publication appears to be a continuation of this orientation towards the Japanese example in the early years of the $20^{\text {th }}$ century. He seemingly felt compelled not to write a history of a European power to gain a deeper understanding of the reasons behind successful unnati and tarakki, but instead chose to write the one of Japan in order to inspire and provoke self-reflection among his readers.

The actual contents of the third part of Śikșādarpaṇa are just as interesting. The first chapter is dedicated to the political history of Japan, starting from the supposedly first Tennō (Jap. heavenly sovereign) of Japan, explaining how the shogunate system was established from the $12^{\text {th }}$ to the $19^{\text {th }}$ century and how the Tennō regained power through the so-called Meiji Restoration from 1868 onwards. This is followed by the argument that to fully grasp the success of Japan, it is necessary to understand the jāpāniko man (Nep. Japanese mind/soul), thus, introducing the reader to Nitobe Inazō's Bushido (1900) and Henry Dyers publications on Japan ${ }^{23}$, thereby, revealing implicitly his major sources (Simha 1907b: 17-21). The first chapter is completed with a historical account of the manifold changes that have taken place between 1868 and the Japanese victory over the Russian Empire in 1905 (ibid: 22). Thereafter, in the chapters on the history of the educational system (ibid: 39 ), the armed forces and shipbuilding (ibid: 44), transportation and communication (ibid: 51), industrial development (ibid: 57), trade (ibid: 65), agriculture (ibid: 73) and finance (ibid: 79), as well as an account of the contemporary political system (ibid: 89) Jaya Prithvi consistently identifies the Japanese strategy to selectively appropriate or mimic European ideas and institutions and apply them modified to their own context. The book ends with three sections on morality titled "Ājādi" (ibid: 102), "Mānyatā" (ibid: 106) and "Pakkāpan" (ibid: 108) that can arguably be understood as a kind of code of conduct. It appears, though, that Jaya Prithvi derived this normative set of morals and virtues through selective appropriation of the ethics described in Bushido. Just as Nitobe Inazō understands Bushido as an ethical system, Jaya Prithvi seeks to formulate a mānyatā (Nep. moral standard). And, similar to Inazō, Jaya Prithvi consistently highlights the importance of namratā (Nep. politeness), ājādi (Nep. integrity) and pakkāpan (Nep. reliability).
This limited analytical exploration of the book series Śikșädarpana shows that the knowledge accumulated by Jaya Prithvi and communicated to his readers through a transcultural lens spans the entirety of the Eurasian continent, thus transcending the discursive boundaries between Europe and Asia. The series commences with a look to 'the West', describing various accounts of European history, before gradually shifting the focus on South Asia. Jaya Prithvi completes his continental panorama in the last book in 'the East' by a detailed analysis of the example of Japan and strong inclination to follow the same. He identifies and reiterates throughout the text an assumedly crucial element of Japan's success: the selective appropriation and contextualized modification of ideas and institutions from European powers.

After Jaya Prithvi accompanied his father-in-law on his journey to Europe in 1908, he published five more books on a variety of subjects. Skāuțingko Noț (1908), Vyavahārmālā (1908) and Bhūgolavidyā (1910) clearly served an instructional purpose, intended to convey specific knowledge to the reader about scouting, behavior, and geography, respectively. Whereas Prākrtvyākaran (1912) and Tattvapraśañsā (1913) in a broader sense were concerned with language issues, the first one very explicitly, being a grammatical analysis of Parvatīya Bhāṣā and the latter more implicitly in the form of a contribution to literature, poetry, and philosophy, written in verse. And, while his grammatical contribution had at least received some attention after the end of Rana rule, the fading interest in his literary work after the establishment of the Panchayat system raises questions about the reasons. One could theorize that because Jaya Prithvi did not belong to the group of now well-known writers and activists like Suryabikram Gyawali (1898-1985), Parasmani Pradhan (1898-1986), Balkrishna Sama (1903-1981), and Dharanidhar Koirala (1893-1980) based in Banaras and Darjeeling in the early $20^{\text {th }}$ century. Historian Pratyoush Onta identifies these intellectuals as part of a "proto-middle class [...] composed of children of poor migrants to India or migrants in search of education in North Indian cities," trying to deploy their cultural capital acquired through educational achievements to differentiate and separate themselves "from the larger Nepali coolie population" (Onta 1996: 67). As a member of the extended Rana family, Jaya Prithvi had been born into and lived a life as part of the ruling elite of the Gorkha state. He might have not been concerned with the project of differentiation of this newly emerging elitist group, but more interested to educate explicitly those parts of the population from which the language activists in Darjeeling and Banaras were trying to separate 
themselves. Unquestionably, the issue deserves more attention in future research projects.

However, it appears that all of Jaya Prithvi's publications in Parvatīya Bhāșā served multiple purposes. All of them were undoubtedly written with the intention to educate the reader on a specific topic, be it language, literature, history, geography, philosophy, bookkeeping, or scouting. Simultaneously, these publications imply that Jaya Prithvi assumed a hierarchically advanced position for himself as part of an educated elite which was supposedly tasked with the 'uplift' of the general population through the dissemination of knowledge and the establishment of a moral standard. Furthermore, his insistence on using Parvatiya Bhāṣā as the medium of communication and education is remarkable for its similarity with Rabindranath Tagore's ideas of education in the vernacular and his critical stance on education in a language that is disconnected from the environment of the student (O'Connell 2020). To explore these possible connections with other educational reform movements of that time in British India and beyond, it should be investigated in the future as to how far Jaya Prithvi was inspired or influenced by Tagore or if he even visited Śāntiniketan either during his time as vakila in Calcutta or later in exile. ${ }^{24}$

Keeping in mind that Jaya Prithvi wrote and published these books during his administrative career, it appears reasonable to assume that he was aware of the emerging need of the Rana administration to construct a national identity. One could further argue that he might have tried to contribute to its cultural foundation, and therethrough, to larger efforts of state-making and nation-building by the Rana administration in the early $20^{\text {th }}$ century, eventually helping to secure the Gorkha state's sovereignty vis-à-vis other powers on the continent, specifically the British Raj. Regardless of this speculation about his personal motivation, the impact is rather obvious: his publications made the contained knowledge more accessible to an audience that had previously been excluded. Moreover, in the vast diversity of knowledge that Jaya Prithvi was aiming to disseminate and expose the people of the Gorkha state to via his writings, the cosmopolitan outlook he apparently envisioned becomes evident, and, at the same time, exemplifies the manifold connections and entanglements of the Central Himalayas with the rest of the world though the circulation of knowledge.

After discussing Jaya Prithvi's earlier works, this last part of the paper introduces his later publications, namely Humanism (1928) and Speeches and Writings (1930). Jaya Prithvi began to write the first drafts of the manuscript for
Humanism in his first years in exile in Naini Tal, though it took until 1928 to finally publish the book. It is composed of three volumes with the general objective "to deal with the problem of Human Troubles" (2019 [1928]: v). In the first volume, titled vividly The Troubles of Man and their Causes, Jaya Prithvi tries to identify the causes of human troubles and discusses what he considers their 'true cause'. He concludes: "Man's suffering on earth are the results of his imperfect Knowledge" of the environment humanity exists in (ibid: 82). He then argues: "As a result of imperfect Knowledge, man sees no unity in others. He sees in them only division and diversity" (ibid: 104). Offering an immediate solution to this identified problem, Jaya Prithvi elaborates at length on the two major elements that constitute this environment: 'The Physical Nature' and 'Human Society,' referencing the gathered knowledge of physics, chemistry, and biology as well as sociology, psychology, and anthropology, and continuously reiterates the importance of a holistic approach in education. In the second volume, titled just as intelligible Man and the Universe, Jaya Prithvi deals with the question of what constitutes 'True Knowledge' of oneself, the environment humanity exists in and their relation to each other. Therefore, he introduces his concept of "Existence" (2019 [1928]: 245 ff.) before ending on several chapters dealing with karma, life and death (ibid: $346 \mathrm{ff}$.). The third volume is titled The Reality of Man and Remedy for Man's Trouble and focusses primarily on his argument for the necessity of religion as a universal part of human existence (2019 [1928]: $455 \mathrm{ff}$.). In the final chapters he then concludes:

Misery is of man's own making, arising out of his wrong perspective of the world and his wrongly directed action. Humanism is a cure to it, certain to rescue mankind from the petty quarrels and competitions of society and rise it above all causes of physical ailments. Man, under it becomes happy not happy by subordinating and owning others, but happy by conquering and correcting his mind, and looking on the world as but the presentation of a common, intelligent Entity that is in him and them. Realisation of that oneness leads to real happiness; but the idea of separateness brings about happiness that is painful in the end. (ibid: 582)

In essence, Humanism appears to be the synthesis of all the knowledge and ideas that Jaya Prithvi acquired in the course of his life until this point and can be understood as the manifestation of his fundamental understanding of the universe, the world, humanity, and their relation to each other. Insofar, Humanism could be described as a kind of manifesto. Further, the book seems to be an attempt to 
encompass all existing knowledge of humanity into one comprehensive argument: his thesis of the basic oneness of everything, which will, when fully realized, create a world that is more than "an abode of Happiness to some and a home of inexpressible and perpetual Misery to many" (2019 [1928]: 1). As Jaya Prithvi was aware and mentioned frequently, he was not the only one expounding such philosophical arguments in his era and he valued the many intellectuals that came before him. However, in opposition to ideologies of nationalism, imperialism and fascism which often dominated intellectual discourses in the early $20^{\text {th }}$ century globally and were based on an essentialist understanding of entities like nations and races that create division and separateness, Jaya Prithvi aimed to thwart these ideas with his idea of humanism, which does not differentiate between the myriad social and cultural groups of the world but explicitly embraces all of humanity. This overarching rebuttal of the creation of separateness and division might offer an explanation why Jaya Prithvi did not get involved with the language activists in Banaras and Darjeeling. It hints at his personal intellectual development from his own educational activism concerned with projects of state-making and nation-building during his service in the Rana administration to an intellectual who became aware of the many problems that the constructing of just another marker of distinction in the form of a national identity could entail.

Besides this, there are also some specific contents in this book which ought to be discussed with regards to the current state of research on Jaya Prithvi's life and work. The prevalent thesis that Jaya Prithvi was one of the earliest leftist thinkers from the Central Himalayas and should be considered as part of the "germination of leftist ideals in Nepal" (Thapa 2004: 21) is not further corroborated by his critical stance regarding the idea of socialism displayed in this publication. He writes:

[...] wherever [socialism] has been pushed ahead, it ended in the display of physical violence to the detriment of the security and the stability of the social order. Man, under guidance of Socialism, has nowhere prospered, but has brought much suffering on his head, and incidentally on that of the wider Society which, through his doctrines, he has attempted to save. (2019 [1928]: 33)

However, the contents of Humanism also inform broader debates on the conceptual history of humanism and are just as significant. The current state of research on the intellectual history of humanistic thought tend to center on Europe and North America. Contemporary publications often argue that the etymology of the term 'humanism' should be regarded as evidence that it is an idea with European origins which disseminated from there through 'the West and the Rest' (Davies 2012 [1997], Copson 2015, Grudin 2020). Although there have been some early critics recognizing this limited perspective (Lévi 1925), and even some more recent publications addressing this desiderate, the scholarly debate remains focused on the cast of the well-known and intensely studied intellectuals like Rabindranath Tagore or ancient Vedic or Buddhist literary sources (Fowler 2015, Tagore 2020). Jaya Prithvi's thoughts, though, have not yet received any scholarly consideration in the intellectual history of humanism.

Noteworthy and a good starting point for future research on Jaya Prithvi's understanding of the idea of humanism is his central hypothesis of the fundamental oneness of humanity. According to him, the most basic needs of self-preservation or survival, followed by the attainment of comfort and happiness unite all human beings. And the only means to fulfill these essential needs is by the realization of this commonality and cooperation which will then, ultimately, lead to the establishment of a global peace order and overall civilizational progress for mankind. As Jaya Prithvi himself consistently acknowledges, this line of reasoning is nothing entirely new. But, in stark contrast to the predominant anthropocentrism and individualism in European and western humanistic thought, Jaya Prithvi's approach is rather critical of the idea of overemphasized human agency and the disregard of supernatural powers that often comes with it. Moreover, he fundamentally disagrees with the binary distinction between secular and religious forms of humanism predominant in the discourses in European and North American academia because it obviously contradicts his essential hypothesis of the basic oneness of everything. He writes in his own words: "Life's division into the Secular and the Spiritual is likely to create cleavage where none exists and to give a false perspective to it and its purpose" (2019 [1928]: 142). Essentially, his use of the term humanism appears to be not indicative of an internalized European or western idea, but a deliberate intellectual appropriation and reinterpretation that speaks to his discursive agency. Therefore, Jaya Prithvi's idea of humanism should be considered a philosophical approach in its own right. As the history of humanistic thought has not yet been an issue debated within 'Global Intellectual History', an in-depth study of Jaya Prithvi's writings could offer an excellent vantage point that could help to further "provincialize" European and North American perspectives in these discourses (Chakrabarty 2009 [2000]), broaden their scope, and deepen our understanding of the global historical 
entanglements of the idea of humanism and the discursive dynamics in the early $20^{\text {th }}$ century.

Jaya Prithvi's second publication in English, Speeches and Writings (1930), is immensely helpful to delve a little deeper and further explore these global intellectual entanglements. The book was published in three separate volumes, with the first one containing the speeches Jaya Prithvi delivered and writings he published in British India between 1928 and 1929. The second book includes all the speeches he gave in Europe between April and July 1929, and the last part consists of the speeches he gave and texts he published after returning to British India in September 1929. Spatial limitations of the paper at hand only allow for a first explorative analysis of the major issues and themes addressed.

First is his concept of 'natural inequality' which he mentions frequently in his speeches and writings, but specifically provides an explanation for in a lecture at the Humanistic Club on 22nd of March 1928 titled InequalityNatural and Unnatural. Jaya Prithvi defines and condemns 'unnatural inequality' as being created by people who "assume an air of superiority and utilize their power to exploit the weaker and perpetrate cruelties of various natures for the satisfaction of their greed, lust, avarice and whims" (1997 [1930]: 8-9). On the other hand, he dismisses the idea of equality being a viable alternative, and instead considers 'natural inequalities' essential, because they supposedly create cooperation, mutual dependence, tolerance towards others, as well as forbearance and forgiveness that "lead to the highest ethical standard that man has ever conceived" (ibid: 8). Towards the end of his lecture, he condenses his argument into the slogan: “'Unity in Diversity' is the principle of the Universe, and not a dead Uniformity" (ibid: 9). ${ }^{25}$ In his speech in Warsaw on $3^{\text {rd }}$ of June 1929 , he elaborates further on the issue of equality and argues that in his view "lasting equality either in respect of wealth or position is impossible. But there is a certain equality which is [...] essentially necessary for the establishment of peace; and this is equality of opportunity" (ibid: 102). The expressed perspective is another clear refutation of central leftist arguments by Jaya Prithvi and could be considered as further debunking the assumption in the current state of research that he could be considered an early leftist intellectual. This critique is further substantiated by his stance on the issue of revolution which he explains in his speech in London on $25^{\text {th }}$ of July 1929:

I believe that every revolution must necessarily be a reaction against and opposition to evolution and hence detrimental and not beneficial to human progress. For, if one set of revolutionaries succeed in overthrowing the existing authority today, tomorrow another set of people, even more revolutionary than the previous one, will try to overthrow the authority then in power. So, as I put it, Revolution works for extinction. (ibid: 134)

The second topic that is featured prominently throughout the book is that Jaya Prithvi's idea of humanism encompasses a strong Sendungsbewusstsein (Ger. sense of mission), implicitly in the fact that he established the Humanistic Club and toured through South Asia and Europe to deliver speeches and open branch offices, but at times also explicitly. He explains, for example, in the second speech in London that after having published Humanism, he soon realized that a book might be insufficient to achieve his objectives. He describes his thought process:

The methods of attaining safety and security, therefore, must be such as would be easily understood by and applied to both the learned and the illiterate, the high and the low, the rich and the poor, religionists and non-religionists alike. (ibid: 127-128)

His Sendungsbewusstsein becomes quite tangible in the speech he gave in Vienna on $11^{\text {th }}$ of May 1929 when he explains: "My methods to bring about peace and goodwill, therefore, are to establish a humanistic club in as many places of every country as possible [...]" (ibid: 77), to then disseminate the humanistic message through its members.

Especially, but not exclusively, in his speeches in Europe, Jaya Prithvi frequently references the 'Great War' and its global impact as the most vivid example for what happens when humans choose to employ violence and brutality over unity and cooperation to achieve their goals. In his speech in Paris on $2^{\text {nd }}$ of July 1929, for example, he explains how the experience of this war "has changed not only the economic and social conditions of the people but also the mentality of the world at large. This change [...] is not restricted to one locality but is found in every part of the world" (ibid: 118). In his first speech in London on $23^{\text {rd }}$ of July 1929 he even mentions the impact it had on his life:

At the risk of being personal, I have to say that, ever since the outbreak of the last world-war, I have been greatly awakened to the problem of peace; peace, not only between nations and countries, but peace between different classes, creeds, parties and communities. (ibid: 123)

This personal note corroborates the previously made assertion that the heavy involvement of the Gorkha state 
in the 'Great War' might have had an influence on the relation between Jaya Prithvi and his father-in-law and possibly had played an important role in the decision to abandon his posts in the Rana administration and leave the Gorkha state permanently. Besides, the latter part of the statement refers to another issue that comes up in many of his speeches and writings, namely his critical view of the League of Nations. Though he generally recognizes the League's objectives as worthy of being supported, he is overly critical of its top-down approach. At a lecture in Bombay on $13^{\text {th }}$ of January 1929, Jaya Prithvi summarizes his critique pointedly as follows:

The League of Nations has for its chief object the establishment of international peace by disarmament and other methods. It does not concern itself with the question of peace between one community and another, between one class and another, between one creed and another, much less between one individual and another, which in my opinion is the more important problem. For, unless peace has been established between the several communities, classes and creeds, beginning with individuals, I am afraid peace between nations is impossible. For, how can you hope for international harmony, if the several societies, classes and parties that make up each nation are at incessant war with one another? (ibid: 38)

Jaya Prithvi instead believes in a bottom-up approach and particularizes this idea in the speech he gave on $23^{\text {rd }}$ of May 1929 in Bucharest, explaining the necessity of the Humanistic Club and the role he envisions for it to play:

What the League of Nations is trying to do among nations and countries, the Humanistic Club endeavours to do among much smaller units as classes, creeds, communities and parties. [...], the Humanistic Club tries to bring about cooperation and unity between the several contending parties, creeds and communities, and make them realise that through goodwill and cooperation they can achieve their ends better than through fighting and violent demonstrations. (ibid: 96-97)

This leads to the last major theme: disillusionment with the assumed civilizational superiority of Europe and 'the West'. At first, Jaya Prithvi is seemingly convinced of this predominant assumption, as his remarks in the inaugural speech at the Humanistic Club on $8^{\text {th }}$ of March 1928 reflect:

The West, in consequence of her vast scientific discoveries, immense wealth acquired through highly organized industries, the territorial acquisitions and solidarity, appears to be the leader of both in spheres of action and thought. The East, on the other hand, is more or less the follower and, to a certain extent, even the imitator of the patterns set by the other. (ibid: 3 )

At his first speech in Berlin, he appears still optimistic and explains that the motivation for choosing Europe as the destination for his lecture tour was his expectation that "after the Great War Europe is in a better position to understand and appreciate the true value of peace, unity and cooperation" (ibid: 66). However, his perspective had already begun to change when he returned to the city for his second speech, admitting:

My visits to the various European countries have hitherto been successful only to impress on me the one idea that all the nations of Europe without exception are today living in an atmosphere of mutual distrust, suspicion and jealousy. [...]. Deep down at the heart of every country, there is found unrest, discontent and suspicion. (ibid: 112)

Until the end of the journey, his frustration with his European audiences and their critique seems to have had continuously progressed throughout his lecture tour. After his return to Bangalore, he first delivered an extensive travel report in the Jaya Bhavan and then dedicated the complete second part of his lecture My Experiences in the West to the critical reflection upon each and every argument and perceived misunderstanding of his philosophy that he had been confronted with. Some critics argued that an instinctive fighting spirit of mankind, the struggle for existence, war, and epidemics are natural phenomenon and could not be altered or avoided by changing behavior. Others regarded the concept of peace as a spiritual idea from 'the East' which will have no appeal to the mind of the materialist 'West'. The socialists declared the abolishment of all distinctions based on status as a precondition for any form of peace, while others opted for the restoration of the old order before the 'Great War.' At the very end of his speech, Jaya Prithvi apparently had to remind himself not to lose hope, and he closes with some remarks which could be understood as reinterpretation of the proclaimed 'civilizing mission' of European colonial powers and a call to action:

I am not pessimistic over this; only, I recognise great obstacles in the way. I hope I may depend on you and such from among the enlightened public who may appreciate my desire to work this Club and make it the means of carrying to the wide 
world the torch of unity and cooperation, peace and goodwill [...]. (ibid: 165)

\section{Preliminary Concluding Remarks and a Brief Outlook:}

The biographical and textual analysis of Jaya Prithvi Bahadur Singh's life and work remains in large part superficial, because of the exploratory approach of the paper at hand. On top of that, the complete body of work could not be comprehensively considered here, because of limited access to source material as well as spatial restriction. However, even this somewhat constrained perspective provides some interesting insights into Jaya Prithvi's personal and intellectual journey. He was born into the ruling elite of the Gorkha state and began his professional career as an idealistic reformer in the Rana administration. Changes in the political landscape of the Gorkha state in the early years of the 20th century then forced him to adapt and become more pragmatic over time in order to be able to operate while not losing sight of his reformist ideals. His diverse publications on language, literature, geography, history, philosophy, and so forth, which served predominantly educational purposes, are indicative of his vast interests, knowledge, and idealism, but also of his efforts to contribute to overarching processes of statemaking and nation-building by the Rana administration.

The outbreak of World War I, the participation of the Gorkha state in it, and the awakening impact that had on him personally, led Jaya Prithvi into self-imposed exile. There, he quickly found new purpose in life as a cosmopolitan philosopher, writer, activist, and founder of the Humanistic Club in Bangalore. Although he had always been a critical observer throughout his life, he evidently admired the scientific achievements and industrial progress of Europe and 'the West' and had to a certain degree internalized some of their ideas, especially those of civilizational progress and their proclaimed civilizational superiority. But, his engagement with the history of Japan, the impressions of the 'Great War' and, finally, the personal experience of his lecture tour through Europe all contributed to his progressing disillusionment with the presupposed leading role of 'the West'. Consequently, as his later publications and actions appear to demonstrate, Jaya Prithvi began to see himself, the Humanistic Club, and its members as the true vanguard for the establishment of a global peace order, destined to take over the role as "torchbearer upon the path of progress" and tasked with their own 'civilizing mission' (Mann 2004; 2011, Osterhammel 2005). By not only echoing, but reinterpreting this ideology of European colonial powers, Jaya Prithvi became a part of the ongoing "intellectual revolt
Stefan Lüder studied Area Studies of Asia and Africa (B.A.), and South- and Southeast Asian Studies (M.A.) at Humboldt University Berlin, University of Vienna and Kathmandu University. Currently, he is a PhD fellow at the Institute for Asian and African Studies at Humboldt University Berlin and his research is funded by a PhD scholarship of the German Academic Scholarship Foundation (Studienstiftung des Deutschen Volkes).

Foremost, I thank my supervisor Dr. Michael Mann for the patient guidance and trust, and the German Academic Scholarship Foundation. I am grateful to the staff at Tribhuvan University Central Library, Madan Puskar Pustakalaya, Martin Chautari, National Archives of India, the Jaya Bhavan. I am indebted to Sudip Lingthep, Min Bahadur Singh and B.N. Niranjan Bhoopalam, Maximilian Engel, Todd John Wallenius, Daniel Dillon, Dr. Joanna Pfaff-Czarnecka, Emily Jean Leischner and the anonymous reviewers for their assistance, inspiration and critical comments. I am deeply thankful to my family for their love and patience. All remaining mistakes are my own.

against the West and the remaking of Asia" (Mishra 2012) in the first half of the $20^{\text {th }}$ century.

What has not been considered here at all and, unquestionably, deserves more attention in future research projects, is the global network of Jaya Prithvi. He presented his ideas to diverse audiences, e.g., scholars, intellectuals, spiritual leaders, politicians, businessmen, activists, and Freemasons alike around the world and could even convince some of them to join his cause. These manifold personal connections of his need to be further investigated in a detailed network analysis. Jaya Prithvi's possible connections and interactions with other intellectuals and activists in Asia, Africa, North America, and Europe offer several promising leads for future research. Nevertheless, this explorative study of Jaya Prithvi Bahadur Singh's life and work offers a glance into some of the multi-layered global historical connections and entanglements of the Central Himalayas with its neighboring regions and the rest of the world through the circulation of ideas and knowledge and, similarly, enriches some larger debates of 'Global Intellectual History' empirically and thematically through the discussion of Jaya Prithvi's thoughts on education, humanism or civilizational progress.

\section{Endnotes}

1. I am referring here to the definition of the term 'Himalayan Massif' as proposed by Sara Shneiderman 
(2010: 290), who adapted and altered it from Jean Michaud's usage of 'Southeast Asian Massif'.

2. The publication of van Schendel (2002) and Scott (2009) have seemingly contributed significantly to the growing interest.

3. Prem R. Uprety argues that through his educational publication Śikșādarpana Jaya Prithvi intended to "throw a 'bombshell' against the Rana regime, without even mentioning the word Rana and Nepal" (Uprety 1992: 23).

4. Simhha, Jayaprthvībahādura. 1997 [1930]. Speeches and Writings of Colonel Raja Jai Prithvi Bahadur Singh, Nepal, Founder President of the Humanistic Club, Bangalore, South India). Kathmandu: Research Academica for Humanism and Jai Prithvi Bahadur Singh (RAFHAJ), Nepal.

_. 1999 [2056 V.S.]. Prākrıtvyākaraṇ. Kathmandu: Research Academica for Humanism and Jai Prithvi Bahadur Singh (RAFHAJ), Nepal.

1999 [2056 V.S.]. Tattvapraśañsā. Kathmandu: Research Academica for Humanism and Jai Prithvi Bahadur Singh (RAFHAJ), Nepal.

—. 2000 [2057 V.S.]. Akșarānika Śikșā. Kathmandu: Research Academica for Humanism and Jai Prithvi Bahadur Singh (RAFHAJ), Nepal.

2005 [2062 V.S.]. Nāgarik Śikșā. Kathmandu: Research Academica for Humanism and Jai Prithvi Bahadur Singh (RAFHAJ), Nepal.

_. 2019 [1928]. Humanism. Vol. I-III. Kathmandu: Humanism and Jai Prithvi Foundation.

5. This is, for example, remarkably obvious in Lama 2003. This same hagiographic tendency but with a distinct local connotation can be seen in Yātrī (1977 [2034 V.S.]).

6. See Gramsci et. al., eds. 2011 [1992].

7. Online access via: https://www.tandfonline.com/toc/ rgih20/current. Accessed 27 May 2021.

8. The rājya (Nep. principality) of Bajhang had been politically integrated into the Gorkha state during the Gorkhali expansion towards the west around 1791. Before the Gorkhali expansion, Bajhang was a sovereign principality and part of the so-called Bāise Rajjya. Due to its ruler's cooperation with the expanding Gorkha state, it could retain a certain degree of independence during the $19^{\text {th }}$ century. But, during Rana rule, the rājya became ever more integrated into and influenced by the power center in Kathmandu, particularly through marriage policies. For the history of Bajhang until the end of the $18^{\text {th }}$ century see
Subedī (1986). For more details on the relation between Bajhang and the Gorkha state in the $19^{\text {th }}$ century see Adhikari (1980).

9. Hence, Jaya Prithvi can be considered part of the extended Rana family, the de facto rulers of the Gorkha state from 1846 until 1951.

10. For more details on the political turmoil following the death of Jung Bahadur Rana see Manandhar (1986).

11. Unfortunately, I was not able to locate neither any source material nor any literature which provides more details on Khagaraja Divyeshwari Rajya Laxmi. That is the reason why she is not further mentioned in this paper.

12. The newspaper Gorkhāpatra continues to be published until today.

13. Literally translated meaning the "language of the hills". Historically, there have been many names used for the language. Sometimes it is referred to as "Gorkhāli", "Gorkhā Bhāșā" or "Khas Kura" and Jaya Prithvi himself called it "Prākrt". It is the language that later developed into modern Nepālī.

14. There has not been any verifiable documentation of exactly how many of those schools were established by Jaya Prithvi under the tutelage of Deva Shamsher Rana, but most researchers agree on around 50 schools across the country, with the majority located within the Kathmandu valley. For a broad overview on educational history from the middle $19^{\text {th }}$ to the middle of the $20^{\text {th }}$ century see Aryal, K.R. (1977). For a much more detailed study see Rizal (1987) and Śarmā (2005 [2062 V.S.]).

15. The school exists and operates until today as a higher secondary school. See Simha (1978 [2035 V.S.]: 10).

16. Because more than 200,000 young men from the Gorkha state had left their villages, the impact was presumably considerable. With a total population of roughly five million, according to the first census in 1911, it means that nearly ten percent of the total male population left the country, probably causing massive difficulties specifically for the agrarian economy in rural areas. For more details see Chhetry (1991) and Caplan (1995).

17. There exists only little source material from this transitional phase of Jaya Prithvi's life and the existing literature often contains conflicting timelines.

18. Unfortunately, I was not able to locate any primary source material related to the Humanistic Club beyond the publications by Jaya Prithvi. Some authors claim that Rabindranath Tagore was supposedly an honorary 
member, but there has not been any documented evidence discovered substantiating the claim. See Lama (2003: 49).

19. These travels are not well documented, but at the time received notable attention in the English language media, as newspaper articles in the New York Times, the Japan Times, China Press and the Shanghai Times, among others. Jaya Prithvi also gave at least two radio interviews: the first one to the National Broadcast Company in Chicago in August 1933 and the second one to YMCA radio Shanghai in November 1933. For details on media coverage of Jaya Prithvi in the early 1930s see Simha et. al. (2003 [2060 V.S.]: 170-171) and Simha (1978 [2035 V.S.]: 62-63).

20. Published from Shillong by Mani Singh Gurung from 1935 to 1938 . See Chalmers (2003: 114).

21. The original text of the newspaper report reads:

Dākvāt khavar āyo ki nepālkā Jayaprthvībahādura Siṃha yas velā avisiniyāmā hunuhuncha.[...]. Yabhandā pahile uhã jāpānmā hunuhunthyo. Ițalī ra avisiniyāko laṛāī suru hunāsāth uhã yahã āunubhaeko cha. [...]. Jāpānvāṭ dū janā dāktar ra cār janā nars pani bolāunubhaeko cha. [...]. (Gorkha Sevak, Māgh 30, 1992 V.S.).

For a reprint of the newspaper report see Simha et. al. (2003 [2060 V.S.]: p. 172).

22. This translation is my own, but it is based on the one prepared by Hriseekesh Upadhyay made for the ongoing collaborative project with Todd John Wallenius for which we focus more specifically on the educational ideas of Jaya Prithvi Bahadur Singh.

The original sentence in the Śikșādarpana: Tesro Bhāg is:

Yeskāraṇ le mulukko unnati kasrī hudo rahecha, bhanne thaha hos bhannā nimitt, jun mulukle thorai varșa bhinnamā tarakki garī, hālai mā sav bhandā thulo rus lāi jityo, so jāpān mulukko choṭkari itihās lekhincha.

23. For an overview on these writings see Dyer and Nobuhiro, eds. (2006).

24. For example, an overview to the connection between educational reform movements in India and Germany see Mann (2015).

25. A principle that later gained prominence in India through Nehru (1946).

\section{References}

Adhikari, Krishna Kant. 1980. "The Status, Power and Functions of Rajas and Rajautas During the Nineteenth Century Nepal in the Light of Contemporary Documents." Contributions to Nepalese Studies (CNS) 8(1): 147-155.

Aryal, Krishna Raj. 1970. Education for the Development of Nepal. Kathmandu: Shanti Prakashan.

1977. “Education During Rana Regime." Nepal Digest: Nepal Education Special, 121-130.

Banskota, Purushottam. 2014 [1994]. The Gurkha Connection: A History of the Gorkha Recruitment in the British Indian Army. New Delhi: Nirala Publications.

Barua, Harendra B. 2002. Śatābdī Pūrva Jāpānamā Adhyayana Garne Agraja Nepālī Vidhyārthīharū: Pioneer Nepali Students in Japan a Century Ago. Kathmandu: Mandala Book Point.

Barbu, Daniel. 2019. “An Interview with Sanjay Subrahmanyam.” Cromohs (Cyber Review of Modern Historiography) 21: 123-132.

Bhațțarāī, Tulsī. 1998 [2055 V.S.]. Mānavatāvādī Jayaprthvī Jivian Sañsār. Dhangadhi, Nepal: Gītā Kuñja.

Beckert, Sven, and Dominic Sachsenmaier. 2018. "Introduction." In Global History, Globally: Research and Practice Around the World, edited by Sven Beckert and Dominic Sachsenmaier, 1-18. London: Bloomsbury Academic.

Burghart, Richard. 1984. "The Formation of the Concept of Nation-State in Nepal." The Journal of Asian Studies 44(1): 101-125.

Caplan, Lionel. 1995. Warrior Gentlemen: "Gurkhas" in the Western Imagination. Providence: Berghahn Books.

Chakrabarty, Dipesh. 2009 [2000]. Provincializing Europe: Postcolonial Thought and Historical Difference. Princeton: Princeton University Press.

Chalmers, Rhoderick. 2003. "We Nepalis: Language, Literature and the Formation of a Nepali Public Sphere in India, 1914-1940." Ph.D. Dissertation, School of Oriental and African Studies, University of London.

Chhetry, Dil Bahadur. 1991. "Chandra Shumsher's Help to the British in the World War I." Rolamba 11(3): 3-9.

Conrad, Sebastian. 2016. What Is Global History? Princeton, Oxford: Princeton University Press. 
Copson, Andrew. 2015. "What Is Humanism." In the Wiley Blackwell Handbook of Humanism, edited by Andrew Copson and A. C. Grayling. Hoboken: Wiley.

Davies, Tony. 2012 [1997]. Humanism. Hoboken: Taylor and Francis.

Des Chene, Mary. 1991. "Relics of Empire: A Cultural History of the Gurkhas." Ph.D. Dissertation, Department of Anthropology, Stanford University.

—. 2007. "Is Nepal in South Asia? The Condition of Non-Postcoloniality." Studies in Nepali History and Society (SINHAS) 12(2): 207-223.

Dixit, Kamal. 1957 [2014 V.S.]. Yesto Pani. Kathmandu: Madan Puraskar Pustakalaya.

Dixit, Madan Mani. 1984 [2041 V.S.]. "Nepālmā Leninvādko Praveś: Prarambhik Tipot.” Chintan.

Dyer, Henry, and Nobuhiro Miyoshi, eds. 2006. The Collected Writings of Henry Dyer: A Collection in Five Volumes. Tokyo: Ed. Synapse.

Foreign and Political Department. 1918. Purchase of Ben Nevis a House in Naini Tal by Colonel Raja Jai Prithvi Bahadur of Nepal. Progs., Nos. 125-126. National Archives of India.

. 1921. Proposed Acquisition by Colonel Raja Jai Prithvi Bahadur Singh of Bajang, Nepal, of a House in the Civil and Military Station of Bangalore. Progs., Nos. 36. National Archives of India.

1928. Disappearance from Calcutta of Raja Jai Prithivi Bahadur Singh, Son-in-Law of His Highness the Prime Minister of Nepal. Progs., Nos, 15. National Archives of India.

1929. Information Supplied to Prime Minister of Nepal Regarding the Departure of Col. Raja Jai Bahadur Singh for England. Progs., Nos, 113. National Archives of India.

1932. Grant of Passport to Raja Jai Prithvi Bahadur Singh Originally a Nepalese Subject, as a British Protected Subject of the Mysore State. Progs., Nos. 348 - G. National Archives of India.

1936. Cancellation of the Passport of Raja Jai Prithvi Bahadur Singh, an Indian State Subject of Mysore. Progs., Nos. 111-X. (Secret). National Archives of India.

Foreign Department. 1903a. Appointment of Colonel Jai Prithvi Bahadur Singh as Representative of the Govt. Of
Nepal at Calcutta. His Interview with His Excellency the Viceroy. Progs., Nos 2-5. National Archives of India.

1903b. Payment of the Usual House Rent to Col. Jai Prithvi Bahadur Singh Representative of the Govt. Of Nepal at Calcutta. Progs., No. 102-105. National Archives of India.

1940. Secret Letter from Foreign Department to Government of United Provinces Regarding Action to Ensure That Raja J.P. Bahadur Singh Does Not Mix with the Nepalese Contingent. Progs. No. F.195-X/39. National Archives of India.

Fowler, Jeaneane. 2015. “The Materialists of Classical India." In the Wiley Blackwell Handbook of Humanism, edited by Andrew Copson and A. C. Grayling, 97-118. Hoboken: Wiley.

Gramsci, Antonio, Joseph A. Buttigieg, and Antonio Callari, eds. 2011 [1992]. Prison Notebooks. New York: Columbia University Press.

Grudin, Robert. 2020. “Humanism.” Encyclopædia Britannica. https://www.britannica.com/topic/humanism. Accessed 27 May 2021.

Gurung, Mani Singh. 12 February 1936 [Māgh 30, 1992 V.S.]. "Jayaprthvībahādura Siṃha Yas Velā Avisiniyāmā Hunuhuncha." Gorkha Sevak.

Gyawali, Bandana. 2017. “Nepal's Pre-Bikās Encounters with the West: Saybhyatā and Unnati as Precursors to Development." Studies in Nepali History and Society (SINHAS) 22(2): 227-260.

2018. "Ambiguous Bikās: History of the Concept of Development in Nepal 1900-2006.” Ph.D. Dissertation, Faculty of Social Sciences, University of Helsinki.

Haakonssen, Knud, and Richard Whatmore. 2017. "Global Possibilities in Intellectual History: A Note on Practice." Global Intellectual History 2(1): 18-29.

Home Department. 1908. Incidence of the Cost of Entertainment of Indian Visitors to England. Case of the Prime Minister of Nepal. Progs., Nos. 263. National Archives of India.

- 1940. Issue of an Order Under Rule 26 (I) (a) of the Defence of India Rules in Respect of Raja Jai Prithvi Bahadur Singh of Nepal. Question as to Which Dept. Is Responsible for Making Such Orders. 59/9. National Archives of India.

Jośī, Manirāj. 2012 [2069 V.S.]. Jayaprthvībahādura Siṃha Mahākāvya. Dhangadhi, Nepal: Sudūr Paścimāñcal Ekeḍemī. 
Khadka, Shyam Bahadur. 2001. Bajhang Myth's and History. Kathmandu: Ekata Book Distributor Pvt. Ltd.

Lama, Dhan Bahadur. 2003. A Humanist in Life and Death. Kathmandu: Dhan Bahadur Lama.

Lévi, Sylvain. 1925. Eastern Humanism: An Address Delivered in the University of Dacca. University of Dacca Bulletin 4. Dacca: University of Dacca.

Liechty, Mark. 1997. “Selective Exclusion: Foreigners, Foreign Goods, and Foreignness in Modern Nepali History." Studies in Nepali History and Society (SINHAS) 2(1): 5-68.

Malla, Katak. 2020a. "A Case for the Need of Humanist Education.” Kathmandu Post. 14 March 2020. https:// kathmandupost.com/books/2020/03/14/a-case-for-theneed-of-humanist-education. Accessed 27 May 2021.

. 2020b. "A Portrait of Public Intellectuals: Jaya Prithivi Bahadaur Singh.” New Spotlight Magazine. 19 March 2020. https://www.spotlightnepal. com/2020/03/19/portrait-public-intellectuals-jayaprithivi-bahadaur-singh/. Accessed 27 May 2021.

Manandhar, Tri Ratna. 1986. Nepal: The Years of Trouble (1877-1885). Kathmandu, Nepal: Purna Devi Manandhar.

Manandhar, Tri Ratna, Krishna Bahadur Thapa, Tirtha Prasad Mishra, Bhaveswor Pageni, and Bishnu Sapkota, eds. 1995. State of Nepali Historiography: Report of a Seminar Organised by the Central Department of History. Kathmandu, Nepal: Tribhuvan University. 12-13 October 1993.

Manandhar, Vijay Kumar, Shanker Thapa, and Bhaveśvara Paṅgenī. 2014. Descriptive Catalogue of Master's Theses in History: Theses Submitted to Central Department of History, PostGraduate Campus - Biratnagar, Thakur Ram Campus - Birganj, Pritivi Narayan Campus - Pokhara. Kathmandu: Central Department of History, Tribhuvan University.

Manandhar, Vijay Kumar, Shanker Thapa, and Bhaveśvara Pañgenī, eds. 2015. Quest for Historical Knowledge: Doctoral Dissertations in History by Nepalese Scholars. Kathmandu: Central Department of History, Tribhuvan University.

Mann, Michael. 2004. “"Torchbearers Upon the Path of Progress': Britain's Ideology of a 'Moral and Material Progress' in India." In Colonialism as Civilizing Mission: Cultural Ideology in British India, edited by Harald FischerTiné and Michael Mann, 1-28. London: Anthem Press.

_ 2011. "Afterword: Improvement, Progress and Development." In Civilizing Missions in Colonial and Postcolonial South Asia: From Improvement to Development, edited by Carey A. Watt and Michael Mann, 317-328. London, New York: Anthem Press.

— ed. 2015. Shantiniketan - Hellerau: New Education in the 'Pedagogic Provinces' of India and Germany. Heidelberg: Draupadi-Verlag.

Michael, Bernardo A. 2011. Nepali History as World History. Baha Occasional Papers 4. Kathmandu: Published for Social Science Baha by Himal Books.

2012. Statemaking and Territory in South Asia: Lessons from the Anglo-Gorkha War (1814-1816). London: Anthem Press.

Michaels, Axel, Manik Lal Bajracharya, Niels Gutschow, Madeleine Herren, Bernd Schneidmüller, Gerald Schwedler, and Astrid Zotter. 2016. "Nepalese History in a European Experience: A Case Study in Transcultural Historiography." History and Theory 55(2): 210-232.

Mikesell, Stephen L. 1988. "Cotton on the Silk Road: Subjection of Labor to the Global Economy in the Shadow of Empire: (or the Dialectic of a Merchant Community in Nepal)." Ph.D. Dissertation, University of Wisconsin Madison.

Mishra, Pankaj. 2012. From the Ruins of Empire: The Revolt Against the West and the Remaking of Asia. New York: Penguin Group.

Moyn, Samuel, and Andrew Sartori, eds. 2013. Global Intellectual History. New York: Columbia University Press.

Mulsow, Martin. 2017. "New Perspectives on Global Intellectual History.” Global Intellectual History 2(1): 1-2.

Nehru, Jawaharlal. 1946. The Discovery of India. Calcutta: The Signet Press.

Nitobe, Inazō. 1900. Bushido: The Soul of Japan: An Exposition of Japanese Thought. Philadelphia: The Leeds \& Biddle Co.

O'Connell, Kathleen. 2020. “Tagore's Santiniketan: Learning Associated with Life." In the Cambridge Companion to Rabindranath Tagore, edited by Sukanta Chaudhuri, 294-308. Cambridge, New York, NY: Cambridge University Press.

Onta, Pratyoush. 1993. "Whatever Happened to the "Golden Age'?” Himal 6(4): 29-31.

—.1994a. "Dukha During the World Wars." Himal Southasian Vol. 7(6): 24-34.

_. 1994b. "Rich Possibilities: Notes on Social History in Nepal." Contributions to Nepalese Studies (CNS) 21(1): 1-43. 
1996a. "Ambivalence Denied: The Making of Rashtriya Itihas in Panchayat Era Textbooks." Contributions to Nepalese Studies (CNS) 23(1): 213-254.

1996b. "Creating a Brave Nepali Nation in British India: The Rethoric of Jati Improvement, Rediscovery of Bhanubhakta and the Writing of Bir History." Studies in Nepali History and Society (SINHAS) 1(1): 37-76.

. 1997. “Activities in a 'Fossil State': Balkrishna Sama and the Improvisation of Nepali Identity." Studies in Nepali History and Society (SINHAS) 2(1): 69-102.

Osterhammel, Jürgen. 2005. "Europe, the 'West' and the Civilizing Mission.” Annual lecture, German Historical Institute, London, London, 2005.

Pande, Bhim Bahadur. 1982 [2039 V.S.]. Tyas Bakhatko Nepāl: 2 Volumes. Kathmandu: Tribbhuvan Viśvavidhyālaya.

Pant, Rāmrāj. 1961 [2018 V.S.]. Bhāṣā Vigyānko Itihās. Kathmandu: Jagadambā Prakāśan.

Parājulī, Śarmilā. 2000 [2057 V.S]. Jayaprthvïbahādura Siṃhako Prākrtvyākaranko Adhyayan. Kathmandu: Tribbhuvan Viśvavidhyālaya.

Parājulī, Lokranjan. 2012. "From Controlling Access to Crafting Minds: Experiments in Education in Late Rana Nepal." Studies in Nepali History and Society (SINHAS) 17 (2): 297-331.

Pinḍ̄āī, Keśavrāj. 23 August 1979 [Bhādre 7, 2036 V.S.] "Rājā Jayaprọthvībahādura Siṃha, Sańkṣipt Paricay." Gorkhāpatra.

Pocock, J. G. A. 2019. “On the Unglobality of Contexts: Cambridge Methods and the History of Political Thought." Global Intellectual History 4(1): 1-14.

Pokharel, Madhav. 2009. "Origin and Development of the Nepali Language." In Indian Nepalis: Issues and Perspectives, edited by Tanka B. Subba, 325-338. New Delhi: Concept Pub. Co.

Political Department. 1939. Rejection of the Offer of One Raja J.P. Bahadur Singh of Nepal to Raise a Small Red Cross Contingent. 2. Decision Not to Allow the Raja to Mix with the Nepalese Contingent in India. 3. Action Taken Againt the Raja Under Rule 26 (1) (D) of Defence of India Rules as Applied to the Civil and Military Station of Bangalore. Progs., Nos. 66-W. National Archives of India.

Pradhan, Kumar. 1991. The Gorkha Conquests: The Process and Consequences of the Unification of Nepal, with Particular Reference to Eastern Nepal. Calcutta: Oxford University Press.
Pradhan, Queeny. 2019. “Introduction: Himalaya and Trans-Himalaya: Connecting Histories, Transcending Disciplines." Südasien-Chronik / South Asia Chronicle 9: 1-15.

Raj, Yogesh. 2014. "Loss of Epistemic Diversity: Academic Historiography in Post-1950 Nepal." Studies in Nepali History and Society (SINHAS) 19 (1): 1-39.

Raj, Yogesh, and Pratyoush Onta. 2014. The State of History Education and Research in Nepal. Chautari Book Series 81. Kathmandu, Nepal: Martin Chautari.

Regmi, Mahesh C. 1963-68. Land Tenure and Taxation in Nepal: Vol. I - IV: Institute for International Studies, University of California, Berkeley.

-1995. Kings and Political Leaders of the Gorkhali Empire, 1768-1814. Hyderabad: Orient Longman.

1999. Imperial Gorkha: An Account of Gorkhali Rule in Kumaun (1791-1815). Delhi: Adroit Publishers.

Rizal, Ghana Shyam. 1987. "History of Education in Nepal: 1851-1951 A.D.” Ph.D. Dissertation, Tribhuvan University.

Rupakheti, Sanjog. 2012. "Leviathan or Paper Tiger: State Making in the Himalayas, 1740-1900.” Ph.D. Dissertation, Rutgers University.

_. 2017. "Beyond Dharmashastras and Weberian Modernity: Law and State Making in Nineteenth-Century Nepal." In Law Addressing Diversity, edited by Gijs Kruijtzer and Thomas Ertl. Berlin, Boston: De Gruyter.

Sachsenmaier, Dominic, and Andrew Sartori. 2018. "The Challenge of the Global in Intellectual History." In Global History, Globally: Research and Practice Around the World, edited by Sven Beckert and Dominic Sachsenmaier, 215-232. London: Bloomsbury Academic.

Said, Edward W. 2004. Humanism and Democratic Criticism. New York: Columbia University Press.

Śarmā, Gopi Nath. 2005 [2062 V.S.]. Nepālmā Śikșāko Itihās. 3rd edition. Kathmandu: Makalu Books.

Śarmā, Govindraprasād. 1998 [2055 V.S.]. Nepālī Vyākaraṇko Aitihāsik Sarvekșan. Kathmandu: Tribbhuvan Viśvavidhyālaya.

Śarmā, Sukum. 1999 [1056 V.S.]. Nepālī Vyākaraṇko Aitihāsik Sarvekșaṇ. Kathmandu: Vaṅmaya Prakāśan.

Saxer, Martin. 2016. "Pathways: A Concept, Field Site and Methodological Approach to Study Remoteness and Connectivity." HIMALAYA 36(2): 104-119. 
Scott, James C. 2009. The Art of Not Being Governed: An Anarchist History of Upland Southeast Asia. New Haven, London: Yale University Press.

Shneiderman, Sara. 2010. "Are the Central Himalayas in Zomia? Some Scholarly and Political Considerations Across Time and Space." Journal of Global History 5(2): 289-312.

Siṃha, Gajendrabahādura. 1989 [2046 V.S.]. Rājā Jayaprthvībahādura Siṃhako Mānavatāvāda Ra Śānti Sandeśa. Kathmandu: Namī Siṃha.

Siṃha, Jayaprothvībahādura. 1901a [1958 V.S.]. Akșarānka Śikṣā. Kathmandu: Paśupat Chāpākhānā.

.1901b [1958 V.S.]. Bālbodh. Kathmandu: Paśupat Chāpākhānā.

—. 1901c [1958 V.S.]. Gyānmālā. Kathmandu: Paśupat Chāpākhānā.

.1901d [1958 V.S.]. Śrestādarpaṇa. Kathmandu: Paśupat Chāpākhānā.

_. 1905a [1962 V.S.]. Padārthatattva Viveka. Kathmandu: Gorkhāpatra Chāpākhānā.

—. 1905b [1962 V.S.]. Śikshādarpaṇa: Pahilo Bhāg. Kathmandu: Gorkhāpatra Chāpākhānā.

. 1907a [1964 V.S.]. Śikshādarpaṇa: Dosro Bhāg. Kathmandu: Gorkhāpatra Chāpākhānā.

—. $1907 b$ [1964 V.S.]. Śikshādarpaṇa: Tesro Bhāg. Kathmandu: Gorkhāpatra Chāpākhānā.

—. 1908 [1965 V.S.]. Vyavahāramālā. Kathmandu: Gorkhāpatra Chāpākhānā.

—_. 1910 [1967 V.S.]. Bhūgolavidyā. Kathmandu: Gorkhāpatra Chāpākhānā.

—_. 1912 [1969 V.S.]. Prākrọtvyākaraṇ. Kathmandu: Gorkhāpatra Chāpākhānā.

__ 1913 [1970 V.S.]. Tattvapraśañsā. Kathmandu: Gorkhāpatra Chāpākhānā.

1930. Speeches and Writings of Colonel Raja Jai Prithvi Bahadur Singh. Bangalore: The National Press.

—. 1931. The Flag of Peace. Bangalore: The National Press.

1997 [1930]. Speeches and Writings of Colonel Raja Jai Prithvi Bahadur Singh, Nepal, Founder President of the Humanistic Club, Bangalore, South India). Kathmandu: Research Academica for Humanism and Jai Prithvi Bahadur Singh (RAFHAJ), Nepal.
_. 1999 [2056 V.S.]. Prākrtvyākaran. Kathmandu: Research Academica for Humanism and Jai Prithvi Bahadur Singh (RAFHAJ), Nepal.

1999 [2056 V.S.]. Tattvapraśañsā. Kathmandu: Research Academica for Humanism and Jai Prithvi Bahadur Singh (RAFHAJ), Nepal.

_. 2000 [2057 V.S.]. Akșarāñka Śikșā. Kathmandu: Research Academica for Humanism and Jai Prithvi Bahadur Singh (RAFHAJ), Nepal.

__ 2005 [2062 V.S.]. Nāgarik Śikṣā. Kathmandu: Research Academica for Humanism and Jai Prithvi Bahadur Singh (RAFHAJ), Nepal.

Siṃha, Jayaprothvībahādura, and Juddhabahādura Rāut. 1908 [1965 V.S.]. Skāuțingko Noț. Kathmandu: Gorkhāpatra Chāpākhānā.

Siṃha, Jayaprọthvībahādura, and P. R. Singarachari. 1928. Humanism: Vol. I-III. Bangalore: Bright and Co.

_. 2019 [1928]. Humanism. Vol. I-III. Kathmandu: Humanism and Jai Prithvi Foundation.

Siṃha, Jayaprthvībahādura, Gajendrabahādura Siṃha, and Ravīndra Bhatțarāī. 2003 [2060 V.S.]. Śāntikā Upāya. Kathmandu: Research Academica for Humanism and Jai Prithvi Bahadur Singh (RAFHAJ), Nepal.

Siṃha, Uttamabahādura. 1978 [2035 V.S.]. Mānavatāvādì Rājā Jayaprthvïbahādura Siṃha: Eka Paricaya. Bajhang, Nepal: Sāvitrī Simha.

—_. 1998 [2055 V.S.]. Mānavatāvādī Jayaprthvī JìvanaSaṃsāra. Dhangadhi, Nepal: Keśavabahādura Canda.

Subedī, Dhanapati. 1990 [2047 V.S.]. Jayaprthvïbahādura Simha: Jivvanī, Vyaktitva Ra Krtitva. Kathmandu: Tribbhuvan Viśvavidhyālaya.

Subedī, Rājārām. 1979 [2036 V.S.]. Rājā Karnela Jayaprthvībahādura Siṃhako Sāmājik, Rājnaitik Drsșți Ra Unko Ek Adhyayan. Kathmandu: Tribbhuvan Viśvavidhyālaya.

_.1986. “The History of Bajhang: 1503-1848 B.S.” Ph.D. Dissertation, Tribbhuvan University.

Subrahmanyam, Sanjay. 2015. "Global Intellectual History Beyond Hegel and Marx." History and Theory 54(1): 126-137.

_. 2017. "Beyond the Usual Suspects: On Intellectual Networks in the Early Modern World." Global Intellectual History 2(1): 30-48.

Surendra, K. C. 1999 [2056 V.S.]. Nepālmā Communist Andolanko Itihās. Kathmandu: Vidhyarti Pustak Bhandar. 
Tagore, Saranindranath. 2020. "Rabindranath Tagore and Humanism." In the Cambridge Companion to Rabindranath Tagore, edited by Sukanta Chaudhuri, 416-429. Cambridge, New York, NY: Cambridge University Press.

Thapa, Deepak. 2004. "Radicalism and the Emergence of the Maoists." In Himalayan People's War: Nepal's Maoist Rebellion, edited by Michael Hutt, 21-38. Bloomington, Indianapolis: Indiana University Press.

Thomson, Ann. 2019. "Global Intellectual History: Some Reflections on Recent Publications." Cromohs (Cyber Review of Modern Historiography) 21: 133-138.

Uprety, Prem R. 1992. Political Awakening in Nepal: The Search for a New Identity. New Delhi: Commonwealth Publ.
Uprety, Sanjeev. 2011. Masculinity and Mimicry: Ranas and Gurkhas. Baha Occasional Papers 5. Kathmandu: Published for Social Science Baha by Himal Books.

Vaidya, Tulsī Rām. 1995. "The Historiography of Nepal: An Analytical Approach." Historia: Journal of History and Culture 1(1): 1-12.

2002. "Present State of Historiography of Nepal." Anveshan: A Research Journal of History and Culture 3(3): 1-11. van Schendel, Willem. 2002. "Geographies of Knowing, Geographies of Ignorance: Jumping Scale in Southeast Asia." Environment and Planning D: Society and Space 20(6): 647-668.

Yātrī, Pūrṇaprakāś N. 1977 [2034 V.S.]. Setīkā Tārā. Biratnagar, Nepal: Himālī Saugāt Prakāśan. 